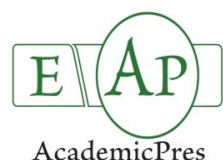

AcademicPres

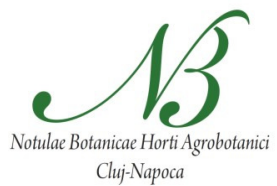

\title{
Physical Parameters and Chemical Composition of Fourteen Blackcurrant Cultivars (Ribes nigrum L.)
}

\author{
Ireneusz OCHMIAN*, Agnieszka DOBROWOLSKA, Piotr CHEŁPIŃSKI
}

\author{
West Pomeranian University of Technology in Szczecin, Faculty of Environmental Managment and Agriculture, Horticulture Department, \\ Stowackiego 17 str.Szczecin 71-424, Poland; ochir@go2.pl, ireneusz.ochmian@zut.edu.pl(*correspondingauthor)
}

\begin{abstract}
The research was conducted in the years 2009-2011 at the Fruit Farming Laboratory of the West Pomeranian University of Technology in Szczecin at the Experimental Station in Ostoja (northwestern Poland). The fourteen blackcurrant bushes of Scottish, Ukrainian and Polish breeding were tested. Physical features of fruits (fruit size, firmness, puncture of the skin, colour, the force required to separate the fruit from the stem) and soluble solids, titratable acidity, $\mathrm{pH}$ and phenolic composition were measured on fresh berries immediately after the harvest were performed on fresh fruits. The 'Ben Alder' cultivar was characterised by the smallest fruits; the weight of 100 fruits from this cultivar was $81.2 \mathrm{~g}$, while the weight of 'Jubilejnaja Kopana', 'Wernisaz', 'Tines' and 'Ben Conan' was over $200 \mathrm{~g}$. The Scottish cultivars from the Ben group, Polish cultivars and Saniuta cultivars were characterised by the greatest firmness and resistance to damage. The 'Ben Alder' cultivar had the highest polyphenol content (789 mg $100 \mathrm{~g}$ of fruits), and anthocyanins were the largest group of compounds. The fruit skins were of a dark colour, and were much darker than the flesh. After the maceration process, the juice was much darker than the fruits, from which it was obtained.
\end{abstract}

Keywords: colors, firmness, fruits quality, maceration, polyphenolic content

\section{Introduction}

The blackcurrant is a plant which has been known for a long time, the first mentions of it already originate from the 11 th century (Sweet, 1999). Wild forms were cultivated 400 years ago and it began to be grown as a commodity crop in Austria at the end of the 19th century as an alternative for endangered vine plantations grape phylloxera (Daktulosphaira vitifoliae) (Peters, 1884). Over 60 cultivars of this species existed already at the beginning of the 20th century (Hummer and Barney, 2002). In Poland, the blackcurrant began to be produced on a greater scale in the 1970s (Makosz, 2007), and at present, its production is the greatest on a global scale. Blackcurrant cultivation is also becoming more and more popular in the USA, where a ban on its cultivation was introduced to protect cultivations of the eastern white pine attacked by white pine blister rust. Cultivation of the white pine blister rust resistant cultivars contributed to revoking the ban (McGlynn, 2006).

Three species had the greatest share in the cultivation of blackcurrant cultivars: $R$. europaeum, $R$. scandinavicum, $R$. sibiricum; however, to obtain resistance to environmental factors and to improve production qualities, genes of species from various parts of the world were introduced: $R$. bracteosum from Alaska, $R$. petiolare from North America, $R$. dikuscha from central Russia, $R$. ussuriense from Manchuria as well as several other species (Keep, 1995; Barney and Hummer, 2005). Cultivation works are conducted at several centres (Brennan, 2008), and the largest gene banks are situated in Russian centres, in Ukraine, Sweden and in the USA (Pluta, 1996). Scottish growers, who noticed that bioactive compounds have a considerable influence on the human body, focused on increasing the contents of not only ascorbic acid, but also anthocyanins (Lipecki and Libik, 2003).

Due to their specific odour and flavour, blackcurrant berries are mostly used in the food processing industry for the production of juice concentrate and frozen products (Makosz, 2006). However, it is fresh berries that are characterised by the highest biological value, which is why breeding works focus mostly on the improvement of taste characteristics of the blackcurrant (Markowski and Pluta, 2003; Pluta and Żurawicz, 2008a). The interest in products rich in bioactive substances is growing, as these compounds are beneficial to health due to the numerous functions they fulfil in the human body. They prevent lifestyle diseases, strengthen the body, reduce stomach problems and indigestion (Halliwell, 2001; Manach et al., 2004), prevent circulatory system diseases by effectively preventing LDL oxidation (Borowska, 2003). Their ability to suppress the activity of free radicals is particularly emphasised (Oszmiański and Sożyński, 1989; Heinonen et al., 1998; Espín et al., 2000; Borowska, 2003; Oszmiański and Wojdyło, 2005). A relationship was also found between the antioxidant activity and the the content of polyphenols and anthocyanins in products (Ehlenfeldt and Prior, 2001; Moyer et al., 2002). Fruits and, in the case of the blackcurrant, juices as this is the main way in which it is used, are a rich source of bioactive compounds with proven pro-health properties. 
In this study, physical and chemical parameters of fruits from several blackcurrant cultivars from various breeding centres were compared with a simultaneous evaluation of their usefulness for mechanical harvesting and pro-health properties.

\section{Materials and methods}

The study was performed in the years 2009-2011 at the Pomiculture Department, West Pomeranian University of Technology in Szczecin. The fourteen blackcurrant bushes breeding Scottish ('Ben Alder', 'Ben Conan', 'Ben Gairn', 'Ben Hope'), Ukrainian ('Jubilejnaja Kopania', 'Saniuta', 'Sjuta Kijewska', 'Sofijewskaja', 'Wernisaż') and Polish ('Ores', 'Ruben', 'Tiben', 'Tines', 'Tisel') were tested. The bushes grew at the Experimental Station in Ostoja (north western Poland) in a luvisol made from boulder clays, this soil was classified as arable land, valuation class IIIa and the good wheat complex.

The soil had a medium-level potassium and phosphorus content and it was rich in magnesium (Tab. 1). Every spring, nitrogen fertilisation was applied at a dose of $60 \mathrm{~kg}$ together with watering using a drip-line irrigation system. Shrubs were planted in 2006 at a spacing of $3.0 \times 1.5 \mathrm{~m}$ in three repetitions in a random subblock system.

Physical features of fruits (fruit size, firmness, puncture of the skin, color, peel the fruit from the pedicel) and soluble solids, titratable acidity $\mathrm{pH}$ and were measured on fresh berries immediately after the harvest were performed on fresh fruits. Phenolics composition was determined in fruit samples that were kept frozen $\left(-32^{\circ} \mathrm{C}\right)$ in polyethylene bags $(500 \mathrm{~g})$ until analyzed.

The fruit weight was measured with RADWAG WPX 4500 electronic scales ( $0.01 \mathrm{~g}$ accuracy). Fruit diameter, firmness and puncture resistance of the skin was measured with a FirmTech2 apparatus (BioWorks, USA) of 100 randomly selected berries from each replicate was expressed as a gram-force causing fruit surface to bend $1 \mathrm{~mm}$. Puncture were made using a stamp with a diameter of $3 \mathrm{~mm}$.

The force required to separate the fruit from the stem was measured by means of a portable Kirschenzipper device manufactured by UP GmbH.

Fruit, pulp, juice and leaves color were measured in a transmitted mode through Konica Minolta CM-700d spectrophotometer in $1 \mathrm{~cm}$-thick glass trays. Measurements were conducted in CIE L*a*b* system [L* white (100) black $(0), a^{*}$ green $(-100)$ red $(+100), b^{*}$ blue $(-100)$ yellow $(+100)]$, through a $10^{\circ}$ observer type and D65 illuminant.

Greening index determined using Chlorophyll Meter SPAD- 502 (Minolta) in SPAD units in autumn, a measurement of leaf surface was performed by means of a DIAS scanner connected to a computer.

After the harvest, the fruits were de-stemmed, next they

Tab. 1. The $\mathrm{pH}$ and the nutrient content in the soil, measured before planting the shrubs

\begin{tabular}{|c|c|c|c|c|c|}
\hline \multirow{2}{*}{$\begin{array}{l}\text { Level of soil } \\
\qquad(\mathrm{cm})\end{array}$} & \multirow{2}{*}{$\begin{array}{l}\mathrm{pH} \\
\mathrm{KCl}\end{array}$} & \multirow{2}{*}{$\begin{array}{c}\text { need for } \\
\text { liming }\end{array}$} & $\mathrm{P}_{2} \mathrm{O}_{5}$ & $\mathrm{~K}_{2} \mathrm{O}$ & $\mathrm{Mg}$ \\
\hline & & & \multicolumn{3}{|c|}{$\mathrm{mg} 100 \mathrm{~g}$ soil } \\
\hline $0-30$ & 6.4 & unnecessary & 14.8 & 8.6 & 8.1 \\
\hline $30-60$ & 6.0 & unnecessary & 9.3 & 11.7 & 4.6 \\
\hline
\end{tabular}

were crushed and the colour of the pulp obtained was determined. To obtain juice, the berries were macerated at $50^{\circ} \mathrm{C}$ with the addition of the PT 400 Pektopol enzyme at a dose of $400 \mathrm{mg}$ per $\mathrm{kg}$ of fruits for 120 minutes. After this time, the colour of the pulp was measured again. After the completion of the enzymatic processing, the pulp was pressed using a hydraulic press at a pressure of $3 \mathrm{MPa}$ and, subsequently, the colour of the juice was determined.

Soluble solids content was determined with a digital refractometer PAL-1 (Atago, Japan). Titratable acidity was determined by titration of a water extract of chokeberry homogenate with $0.1 \mathrm{~N} \mathrm{NaOH}$ to an end point of $\mathrm{pH} 8.1$ (measured with an multimeter Elmetron CX-732) according to PN-90/A-75101/04.

The HPLC analyses of polyphenols were carried out with HPLC apparatus consisting of a Merck-Hitachi L7455 diode array detector (DAD) and quaternary pump L1197100 equipped with D-7000 HSM Multisolvent Delivery System (Merck-Hitachi, Tokyo, Japan). The runs were monitored for phenolic acids at $320 \mathrm{~nm}$, flavonols and luteolin glucoside at $360 \mathrm{~nm}$, and anthocyanin glycosides at $520 \mathrm{~nm}$. Retention times and spectra were compared to that of pure standards and total polyphenols content was expressed as mg per $100 \mathrm{~g}$ fruit tissue. Standards of anthocyanidin glycosides were obtained from Polyphenols Laboratories (Norway), while, for phenolic acids, flavonols and from Extrasynthese (France).

The values were evaluated by the Tukey test and the differences at $p<0.05$ were considered significant. The statistical analyses were performed using the Statistica 10.0 software (Statsoft, Poland).

\section{Results and discussion}

The size of fruits, apart from their chemical composition, is one of parameters defining the yield quality. During the assessment of physical parameters of blackcurrant berries, it was found that the 'Ben Alder' cultivar is characterised by the smallest fruits, their diameter was $12.7 \mathrm{~mm}$, and 100 fruits weighed $81.2 \mathrm{~g}$ (Tab. 2). Similar results were obtained in a research conducted by Rousseau et al. (2002) and Pluta et al. (2005). The greatest weight of 100 fruits (over $200 \mathrm{~g}$ ) was found in the 'Jubilejnaja Kopana', 'Wernisaż', 'Tines' and 'Ben Conan' cultivars; the fruits from these cultivars were also characterised by the longest diameters. In a research by Pluta et al. (2007), the 'Jubilejnaja Kopana' cultivar was also characterised by the largest fruits out of over 10 cultivars under analysis; however, the unit weight of fruits was much less, as compared to the results presented in this study. Fruits from the 'Tiben', 'Ruben' and 'Ores' cultivars reached a slightly lower weight in a research conducted by Pluta and Zurawicz (2008b), as compared to the fruits analyzed in this study.

The firmness of the fruits, their susceptibility to damage and the force required to separate the fruit from the stem largely determine the usefulness of the individual cultivars for mechanical harvesting. The fruits of the 'Tiben', 'Ben Hope', 'Saniuta' and 'Ruben' cultivars were characterized by the greatest firmness as well as by high puncture resistance of the skin, which was much higher than in fruits of lowbusch and highbush blueberry (Ochmian et al., 2008; 
Tab. 2. Quality of fourteen cultivars of tested blackcurrant fruit

\begin{tabular}{|c|c|c|c|c|c|c|c|c|}
\hline Cultivar & $\begin{array}{l}\text { Mass of } 100 \\
\text { fruits }(\mathrm{g})\end{array}$ & $\begin{array}{c}\text { Fruits } \\
\text { diameter } \\
(\mathrm{mm})\end{array}$ & $\begin{array}{l}\text { Firmness } \\
\left(\mathrm{G} \cdot \mathrm{mm}^{-1}\right)\end{array}$ & $\begin{array}{l}\text { Puncture } \\
\left(\mathrm{G} \cdot \mathrm{mm}^{-1}\right)\end{array}$ & $\begin{array}{l}\text { Peel the fruit } \\
\text { from the } \\
\text { pedicel }(\mathrm{g})\end{array}$ & $\begin{array}{c}\text { Soluble } \\
\text { solids } \\
(\%)\end{array}$ & $\begin{array}{l}\text { Titratable acidity } \\
\quad\left(\mathrm{g} \cdot 100 \mathrm{~mL}^{-1}\right)\end{array}$ & Juice $\mathrm{pH}$ \\
\hline Ben Alder & 81.2 & 12.7 & 207 & 111 & 113 & 15.8 & 3.12 & 3.41 \\
\hline Ben Conan & 208.5 & 17.1 & 199 & 111 & 145 & 14.1 & 3.3 & 3.37 \\
\hline Ben Gairn & 165.3 & 15.7 & 206 & 94 & 138 & 16.3 & 2.7 & 3.43 \\
\hline Ben Hope & 134.7 & 14.5 & 276 & 133 & 159 & 15.0 & 2.82 & 3.32 \\
\hline $\begin{array}{l}\text { Jubilejnaja } \\
\text { Kopania }\end{array}$ & 248.5 & 18.1 & 131 & 61 & 194 & 14.8 & 2.4 & 3.43 \\
\hline Saniuta & 167.2 & 15.9 & 250 & 124 & 168 & 15.3 & 2.88 & 3.38 \\
\hline $\begin{array}{c}\text { Sjuta } \\
\text { Kijewska }\end{array}$ & 157.6 & 16.0 & 125 & 64 & 126 & 13.7 & 2.28 & 3.47 \\
\hline Sofijewskaja & 127.1 & 15.2 & 146 & 74 & 85 & 16.2 & 2.88 & 3.40 \\
\hline Wernisaż & 214.7 & 17.4 & 143 & 81 & 113 & 13.5 & 2.64 & 3.41 \\
\hline Ores & 153.6 & 15.6 & 183 & 99 & 152 & 14.8 & 3.3 & 3.39 \\
\hline Ruben & 172.1 & 16.6 & 220 & 110 & 139 & 15.0 & 2.88 & 3.36 \\
\hline Tiben & 124.6 & 15.3 & 279 & 153 & 176 & 16.1 & 3.42 & 3.30 \\
\hline Tines & 210.1 & 17.8 & 191 & 77 & 158 & 16.6 & 2.94 & 3.41 \\
\hline Tisel & 198.7 & 17.6 & 189 & 82 & 137 & 17.5 & 3.12 & 3.32 \\
\hline $\mathrm{LSD}_{0,05}{ }^{*}$ & 47 & 1.9 & 37 & 22 & 31 & 0.35 & 0.23 & 0.18 \\
\hline
\end{tabular}

** The values were evaluated at $\mathrm{P}<0.05$ according to the Tukey test

Ochmian, 2013).

The high firmness of the blackcurrant is also confirmed by research conducted by Viskelis et al. (2010). Fruits from the 'Tiben' and 'Jubilejnaja Kopania' also required the greatest force to separate the fruit from the stem, and were over 170 g. Fruits of the 'Sjuta Kijewska' cultivar were characterized by the lowest firmness, skin puncture resistance and the lowest force required to separate the fruit from the stem $(85 \mathrm{~g})$. Soft fruits were also collected from shrubs of the 'Jubilejnaja Kopania', 'Sofijewskaja' and 'Wernisaż' cultivars; their firmness was comparable to the firmness of blue honeysuckle (Lonicera caerulea var. kamtschatica) (Ochmian et al., 2009).

Important characteristics determining the blackcurrant usefulness for processing include the acid content (at least $\left.2.67 \mathrm{~g} \cdot 100 \mathrm{~mL}^{-1}\right)$ and the extract content $(>10.5 \%)$. A low acid level and the highest possible extract content are important for direct consumption. The fruits of all cultivars under analysis were characterized by the extract content required by the processing industry. The highest extract content was found in fruits from the 'Tisel' cultivar, it was also relatively high in the 'Tines' and Ben Gairn cultivars. 'Wernisaż' and 'Sjuta Kijewska' cultivars were characterised by the lowest extract content. Among the cultivars under analysis, the 'Tiben', 'Ben Conan' and 'Ores' cultivars were characterised by the highest acidity. Blackcurrant cultivars were characterised by a high organic acid and extract content in research conducted by Mladin et al. (2009). The 'Sjuta Kijewska', 'Jubilejnaja Kopania' and 'Wernisaż' cultivars were characterised by a low organic acid content, lower than the standards provided for the food processing industry. Fruits from the 'Jubilejnaja Kopania' cultivars had the most advantageous acid/sugar ratio (amounting to $1: 6.2$ ), which influenced their relatively mild taste and, thus, high usefulness for consumption of fresh fruits.

The high polyphenol content, especially of anthocya- nins, vitamin $C$ and other biologically active substances results in the fruits and products obtained from these fruits are valued as pro-health products. Therefore, two-thirds of the Polish yield are exported.

Polyphenols are secondarily synthesised products, which protect against ultraviolet radiation and pathogens (De Gara et al., 2003; Hodges et al., 2004). Their content largely depends on the cultivar (Mikkonen et al., 2001), and their antioxidant potential decreases together with the degree of fruit ripeness (Wang and Jiao, 2001). The cultivars under analysis differed in terms of the content of polyphenolic compounds. The fruits from the 'Ben Alder' cultivar had the highest polyphenol content $(789 \mathrm{mg})$, the polyphenol content was also high in the 'Saniuta', 'Jubilejnaja Kopania' and 'Tines' cultivars. The lowest content of polyphenols was found in the 'Ben Conan' and 'Tiben' cultivars (Tab. 4). The content of the individual polyphenols in blackcurrant fruits also varied. Anthocyanins constituted the largest group of compounds (Fig. 1). 'Ben Alder' fruits contained $759 \mathrm{mg}$ of anthocyanins, which accounted for $96 \%$ of all determined polyphenolic compounds. Bakowska-Barczak and Kolodziejczyk (2011) found the polyphenol content in fruits from this cultivar to be nearly twice as low $(394 \mathrm{mg})$, while their results pertaining to the 'Ben Conan' cultivar were similar to those obtained in this study. 8 compounds from the anthocyanin group were identified in the research. Wu et al. (2004) identified 14 anthocyanins in black currant, but Milivojevic et al. (2012) found 8. The results of the analyses showed that the delphinidin-3-O-rutinoside content was the highest of all the anthocyanins. Blackcurrant fruits were also characterised by a high content of delphinidin-3-O-rutinoside and delphinidin-3-O-glucoside. The high content of these polyphenols and especially of delphinidin-3-O-rutinoside ( $47 \%$ of all polyphenols) is confirmed by research by Kalisz and Ścibisz (2010). 


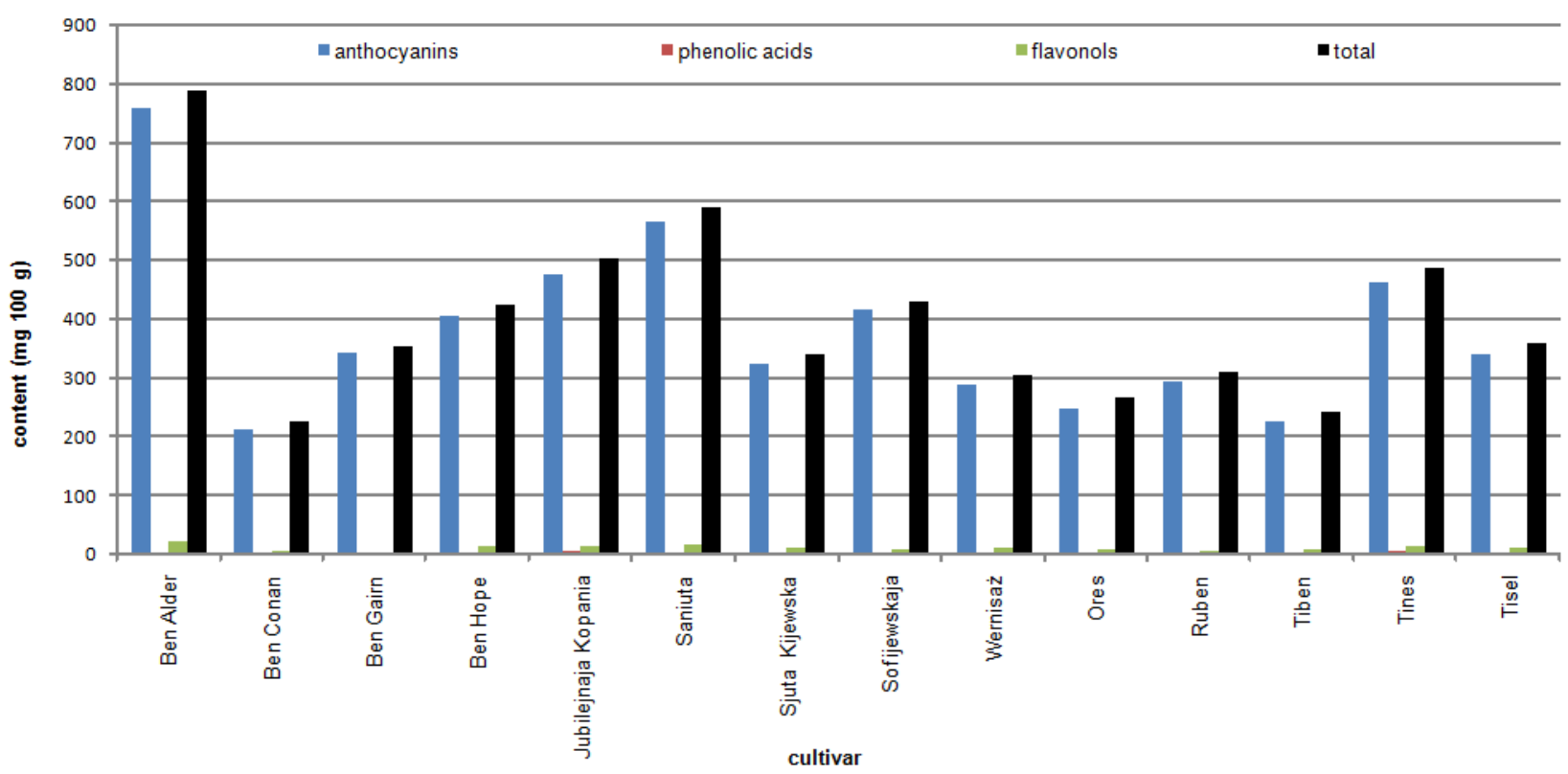

Fig. 1. The content of polyphenolic compounds in fruit of fourteen blackcurrant cultivars

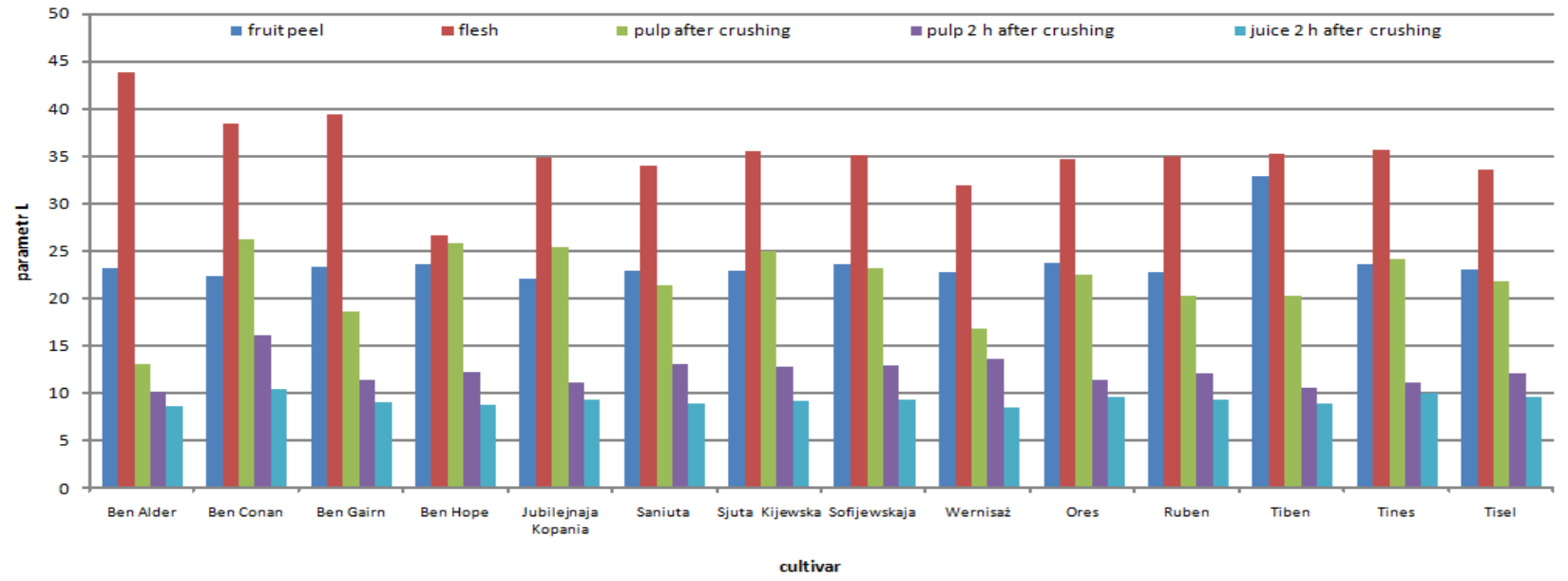

Fig. 2. Fourteen blackcurrant cultivars fruit colour (parameter $L^{*}$ - white 100; black 0 ) and its changes in the pulp after 2 hours maceration

During the research, measurements of the fruit surface colour, the flesh and the pulp prepared from these fruits were performed (Tab. 3, Fig. 2). The component parameters of the fruit surface colour were at a similar level for the fruits from the cultivars under analysis. This can indicate a similar degree of fruit ripeness. Only the Tiben cultivar fruits were characterised by a significantly lighter skin ( $\mathrm{L}^{*}$ $32,80)$. The $L^{*}$ fell within the $22.01-23.63$ for the other cultivars. The variance analysis conducted showed that the skin was the darkest in the 'Jubilejnaja Kopania' and 'Ben Conan' cultivars. The measurement also showed that the $\mathrm{a}^{*}$ parameter for the majority of the cultivars assumed negative values, which, however, did not exceed -1 (green colour). The $\mathrm{a}^{*}$ parameter value was positive only for the 'Sjuta Kijewska' cultivar and it amounted to 0.90 - red colour
(Tab. 3). The assessment of the $b^{*}$ parameter revealed that it was the highest for the 'Tiben' cultivar ( $\left.b^{*} 9.53\right)$. In the 'Ben Alder' and 'Ben Hope' cultivars, the $b^{*}$ parameter assumed negative values.

The flesh colour was significantly different from the fruit surface; it was much lighter with a yellow-red colour. Significantly greater differences were also observed in the flesh colour between the cultivars under analysis. The fruits from the 'Ben Alder' cultivar were characterized by the lightest flesh colour, while the flesh of the 'Ben Hope' cultivar was the darkest (parameter $\mathrm{L}^{*}$ ). In the majority of the cultivars under evaluation, the fruit flesh colour was slightly reddish (parameter $\mathrm{a}^{*}$ ) and yellow (parameter $\mathrm{b}^{*}$ ). The parameter $\mathrm{a}^{*}$ had the highest values for the 'Tiben' and 'Sofijewskaja' cultivars. Only for the 'Sjuta Kijewska' and 
164

Tab. 3. The content of polyphenolic compounds in fruit of fourteen cultivars blackcurrant

\begin{tabular}{|c|c|c|c|c|c|c|c|c|c|c|c|c|c|c|c|c|}
\hline \multirow[b]{3}{*}{ Cultivar } & \multicolumn{15}{|c|}{ 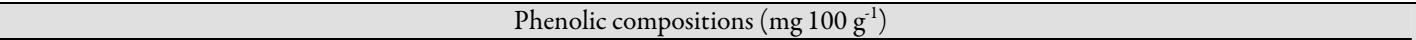 } & \multirow{3}{*}{$\begin{array}{l}\text { Total } \\
\text { LSD }_{0,05} \\
-51\end{array}$} \\
\hline & \multicolumn{8}{|c|}{ Anthocyanins } & \multicolumn{3}{|c|}{ Phenolic acid } & \multicolumn{4}{|c|}{ Flavonols } & \\
\hline & $\begin{array}{l}\text { Del- } \\
\text { glu* }^{*}\end{array}$ & Del-rut & $\begin{array}{c}\text { Del } \\
\text { coum- } \\
\text { glu }\end{array}$ & $\begin{array}{l}\text { Cya- } \\
\text { glu }\end{array}$ & $\begin{array}{l}\text { Cya- } \\
\text { rut }\end{array}$ & $\begin{array}{l}\text { Cya 3- } \\
6 \text { kum }\end{array}$ & $\begin{array}{c}\text { Peo- } \\
\text { rut }\end{array}$ & $\begin{array}{c}\text { Mal- } \\
\text { rut }\end{array}$ & Neochlor & PCQ & M1 & M2 & QRUT & QGAL & QGLU & \\
\hline Ben Alder & 179.7 & 347.9 & 7.49 & 45.4 & 172.3 & 1.985 & 3.23 & 1.54 & 2.44 & 0.75 & 1.53 & 15.20 & 2.09 & 3.67 & 3.33 & 789 \\
\hline $\begin{array}{c}\text { Ben } \\
\text { Conan }\end{array}$ & 47.6 & 97.1 & 9.17 & 10.7 & 45.6 & 2.04 & 1.71 & 0.87 & 3.15 & 0.67 & 0.40 & 4.23 & 0.64 & 1.41 & 1.84 & 227 \\
\hline Ben Gairn & 59.3 & 196.6 & 1.96 & 9.6 & 71.4 & 0.24 & 2.46 & 1.28 & 3.22 & 1.45 & 0.47 & 2.85 & 0.47 & 1.41 & 1.50 & 354 \\
\hline Ben Hope & 59.6 & 218.6 & 2.33 & 16.7 & 103.9 & 0.88 & 1.76 & 0.76 & 4.02 & 1.30 & 1.80 & 5.65 & 1.46 & 2.50 & 3.68 & 425 \\
\hline $\begin{array}{c}\text { Jubilejnaja } \\
\text { Kopania }\end{array}$ & 78.0 & 251.0 & 3.38 & 21.1 & 116.9 & 0.99 & 3.14 & 1.31 & 5.26 & 3.65 & 2.82 & 6.44 & 1.94 & 4.06 & 2.29 & 502 \\
\hline Saniuta & 116.8 & 267.2 & 6.31 & 27.3 & 140.8 & 1.30 & 3.89 & 2.51 & 2.76 & 1.22 & 1.55 & 10.21 & 2.81 & 2.71 & 2.03 & 589 \\
\hline $\begin{array}{c}\text { Sjuta } \\
\text { Kijewska }\end{array}$ & 48.5 & 181.6 & 3.32 & 12.2 & 74.1 & 1.49 & 1.06 & 0.24 & 3.04 & 0.35 & 1.96 & 4.70 & 0.79 & 4.11 & 2.36 & 340 \\
\hline Sofijewskaja & 72.5 & 200.5 & 3.02 & 18.2 & 109.2 & 7.95 & 3.81 & 2.59 & 2.34 & 0.92 & 0.83 & 5.04 & 1.11 & 2.79 & 2.43 & 433 \\
\hline Wernisaż & 37.8 & 177.2 & 2.66 & 6.7 & 61.2 & 0.42 & 1.67 & 0.59 & 2.91 & 1.08 & 1.25 & 4.50 & 2.23 & 2.34 & 2.45 & 305 \\
\hline Ores & 55.7 & 109.1 & 0.82 & 14.2 & 63.5 & 0.29 & 2.90 & 1.85 & 4.49 & 1.01 & 1.45 & 4.05 & 1.02 & 1.69 & 3.89 & 266 \\
\hline Ruben & 75.0 & 142.7 & 1.76 & 13.8 & 57.6 & 0.48 & 2.28 & 1.13 & 3.29 & 2.78 & 0.53 & 4.15 & 1.27 & 1.85 & 1.43 & 310 \\
\hline Tiben & 41.2 & 110.3 & 0.86 & 13.9 & 55.7 & 0.25 & 2.95 & 2.01 & 4.39 & 0.99 & 1.11 & 3.27 & 1.05 & 0.71 & 3.83 & 242 \\
\hline Tines & 87.1 & 264.9 & 3.79 & 13.1 & 87.0 & 0.46 & 4.09 & 1.61 & 6.75 & 2.39 & 1.16 & 7.52 & 1.41 & 2.96 & 2.81 & 487 \\
\hline Tisel & 68.0 & 163.4 & 5.06 & 16.8 & 81.1 & 1.41 & 2.40 & 1.44 & 3.55 & 1.83 & 1.12 & 5.84 & 1.38 & 2.52 & 2.45 & 358 \\
\hline $\mathrm{LSD}_{0,05}$ & 5.1 & 11.2 & 0.48 & 3.4 & 6.9 & 0.26 & 0.67 & 0.31 & 1.17 & 0.45 & 0.41 & 0.98 & 0.76 & 0.62 & 0.36 & \\
\hline $\begin{array}{c}\text { mean } \\
\text { LSD }_{0,05}{ }^{* *} \text { - } \\
2,43\end{array}$ & 73.34 & 194.86 & 7.79 & 17.12 & 88.59 & 1.44 & 2.67 & 1.41 & 3.69 & 1.46 & 1.28 & 5.98 & 1.41 & 2.48 & 2.59 & \\
\hline
\end{tabular}

*explanations: Del-glu - Delphinidin 3-O-glucoside; Del-rut - Delphinidin 3-O-rutinoside; Del coum-glu - Delphinidin-3-O-(6 -p-coumaroyl)glucoside; Cya-glu Cyanidin 3-O-glucoside; Cya-rut - Cyanidin 3-O-rutinoside; Cya 3- $6 \mathrm{kum}$ - Cyanidin 3-O-glucoside-6-p-cumaryl; Peo-rut - Peonidin 3-O- rutinoside; Mal-rut Malvidin 3-O-rutinoside; Neochlor - neochlorogenic acid; PCQ - p-coumaric acid glucoside;M1 - myricetin derivatives t.r. 27,37;M2 -myricetin derivatives t.r. 27,67; QRUT - Quercetin 3-O-rutinoside; QGAL - Quercetin 3-O-galactoside; QGLU - Quercetin 3-O-glucoside ${ }^{* *}$ See Tab. 2.

'Ben Conan', the parameter $\mathrm{a}^{*}$ assumed negative values, which indicate the green colour. The parameter $b^{*}$ defining the yellow colour of the flesh was the highest in the 'Tiben', 'Wernisaż', 'Saniuta', 'Ruben' and 'Ben Conan', cultivar and it was the lowest in the 'Ben Hope' cultivar (Tab. 3).

The content of polyphenolic compounds is higher in the fruit skin than in the flesh (Chang et al., 2000; Eberhardt et al., 2000). Therefore, maceration has a beneficial effect on the pulp and juice colour. To obtain more comprehensive characteristics of the colour of the juices under analysis, the colour was measured in the passing light using the photocolorimetric method in the CIE L*a*b* system. The pulp intensity and also that of the juice prepared using the blackcurrant fruits are determined by the skin colour, which was much darker than the flesh in all of the cultivars. Directly after crushing the fruits, the $\mathrm{L}^{*}$ parameter values of the pulp were similar to those of the skin (Fig. 1). Only in the 'Tiben', 'Ben Alder', 'Wernisaż and 'Ben Gairn' cultivars, the skin colour was distinctly lighter than the colour of the pulp made from these fruits. This shows a very fast maceration process, during which colouring compounds are released from the skin to the pulp. It was found that the pulp colour became darker during maceration conducted in the presence of enzymes. The lowest values of the $\mathrm{L}^{*}$ parameter were found in the 'Ben Alder', 'Tiben', 'Ores' and 'Jubilejnaja' cultivars. The lightest pulp and juice were obtained from 'Ben Conan' fruits. Nevertheless, all juices obtained from blackcurrant fruits were darker than the pulp subjected to maceration (Fig. 1). Juices obtained in the author's research were lighter than juices obtained from blackcurrant concentrates $\left(L^{*} 5.84\right)$ described in the research by Kalisz and Wolniak (2007). However, they were darker than juices produced from wingrapes juices (Ochmian $e t$ al., 2012). No significant correlation was found between the juice colour (parameter $\mathrm{L}^{*}$ ) and the anthocyanin content in the fruits. The fruits from the 'Wernisaż' cultivar were characterised by the darkest juice, while the anthocyanin content was at a low level.

During the tests, also parameters of the blackcurrant leaves were determined. Variance analysis revealed that the cultivars under analysis differed from each other in the leaf colour and size (Tab. 5). The leaf surface area shows the plant productivity and condition. It also undoubtedly depends on the cultivar as it is affected by the size of shrubs. The 'Ben Hope' $\left(67.3 \mathrm{~cm}^{2}\right)$ was characterised by the largest leaf, large leaves also occurred in the 'Ben Conan', 'Wernisaż and 'Ores' cultivars. The 'Ben Alder' cultivar had definitely the smallest leaves - their surface area was only 26 $\mathrm{cm}^{2}$, and the total surface area of leaves from one shrub was $0.87 \mathrm{~m}^{2}$. By far, shrubs from the 'Ores' cultivar had the largest assimilative surface $\left(3.93 \mathrm{~m}^{2}\right)$.

Leaves of blackcurrant cultivars were characterised by a relatively dark colour (the $\mathrm{L}^{*}$ parameter); the 'Tines', 'Sofijewskaja', 'Ruben', 'Tisel' and 'Ben Conan' cultivars had the darkest leaves, while the 'Ben Hope' leaves were the lightest.

An analysis of the $\mathrm{a}^{*}$ parameter, which informs about the location in the colour space between red and green, revealed that it had the lowest (negative) value in the 'Ben Hope', 'Ben Alder' and 'Tiben' cultivars. The 'Ben Alder', 'Ben Hope', as well as 'Ben Conan', 'Tines' and 'Sjuta Kijewskaja' cultivars were also characterised by the lowest chlorophyll index (Gregorczyk and Raczyńska, 1997). The correlation between the $a^{*}$ parameter and the chlorophyll index (SPAD) proved highly significant, which allows for the 
determination of the chlorophyll content using a Konica Minolta spectrophotometer. Similar relationships were obtained in research on Amelanchier species (Ochmian et al., 2013). Also, a significant correlation was found between the $b^{*}$ parameter and the chlorophyll index.

The $b^{*}$ parameter, which defines the location in the colour space between blue and yellow, was the lowest for the 'Sofijewskaja' cultivar, as well as for 'Ruben', 'Ben Conan' and 'Tines', and the highest for the 'Ben Hope' and 'Wernisaż' cultivars.

\section{Conclusions}

The Scottish-bred ben cultivars, Polish-bred cultivars and the 'Saniuta' cultivar were characterised by the greatest firmness and resistance to damage. These characteristics can be advantageous for mechanical harvesting. All the cultivars under analysis have an extract content required for processing purposes; however, the acidity of the 'Sjuta Kijewska', 'Jubilejnaja Kopania' and 'Wernisaż' cultivars does not meet the required values. They are characterised by a mild taste, owing to which they are suitable for direct consumption. The blackcurrant cultivars under analysis show considerable diversity in terms of polyphenol content, and thus, their pro-health properties. Anthocyanins have the highest share in the total polyphenol content. The 'Ben Alder' cultivar is the most valuable in this respect as well as the 'Saniuta', 'Jublejnaja Kopania' and 'Tines' cultivars.

Fruits of the cultivars under analysis are characterised by a similar dark colour of the skin, which is much darker than the flesh colour (the $\mathrm{L}^{*}$ parameter). In the maceration process, the colouring compounds are mostly released to the pulp and juice obtained from these fruits.

As regards the colour of blackcurrant leaves, the $\mathrm{a}^{*}$ and $b^{*}$ parameters are correlated with the chlorophyll index (SPAD), which allows for determining the

Tab. 4. Fruit colour in CIE L*a* $\mathrm{b}^{*}$ of fourteen blackcurrant cultivars

\begin{tabular}{|c|c|c|c|c|c|c|}
\hline \multirow{2}{*}{ Cultivar } & \multicolumn{3}{|c|}{ Colour of the fruit surface $\left(\right.$ CIE L $\left.\mathrm{L}^{*} \mathrm{a}^{*}\right)$} & \multicolumn{3}{|c|}{ Colour of flesh (CIE L*a*b*) } \\
\hline & $\mathrm{L}^{*}$ & $\mathrm{a}^{*}$ & $\mathrm{~b}^{*}$ & $\mathrm{~L}^{*}$ & $\mathrm{a}^{*}$ & $b^{*}$ \\
\hline Ben Alder & 23.19 & -0.15 & -0.62 & 43.70 & 2.52 & 12.18 \\
\hline Ben Conan & 22.36 & -0.11 & -0.29 & 38.40 & -0.14 & 13.72 \\
\hline Ben Gairn & 23.23 & -0.53 & -0.33 & 39.33 & 3.35 & 11.48 \\
\hline Ben Hope & 23.61 & -0.51 & -0.57 & 26.54 & 0.20 & 4.01 \\
\hline Jubilejnaja Kopania & 22.01 & -0.11 & -0.32 & 34.80 & 1.13 & 10.18 \\
\hline Saniuta & 22.81 & -0.56 & 0.12 & 33.91 & 2.93 & 14.05 \\
\hline Sjuta Kijewska & 22.91 & 0.90 & -0.12 & 35.44 & -0.99 & 12.58 \\
\hline Sofijewskaja & 23.59 & -0.47 & -0.24 & 35.00 & 4.06 & 11.14 \\
\hline Wernisaż & 22.70 & -0.39 & 0.33 & 31.87 & 3.45 & 14.48 \\
\hline Ores & 23.63 & -0.47 & -0.31 & 34.67 & 3.22 & 10.93 \\
\hline Ruben & 22.73 & -0.08 & 0.15 & 34.89 & 1.35 & 13.83 \\
\hline Tiben & 32.80 & 0.76 & 1.53 & 35.12 & 5.02 & 16.02 \\
\hline Tines & 23.54 & -0.26 & -0.03 & 35.55 & 1.86 & 8.55 \\
\hline Tisel & 23.03 & -0.32 & 0.19 & 33.48 & 2.80 & 8.81 \\
\hline $\operatorname{LSD}_{0,05}{ }^{* *}$ & 0.39 & 0.12 & 0.26 & 2.17 & 1.35 & 2.71 \\
\hline
\end{tabular}

Tab. 5. The colour and size of leaves of 14 blackcurrant cultivars

\begin{tabular}{|c|c|c|c|c|c|c|}
\hline \multirow{2}{*}{ Cultivar } & \multicolumn{3}{|c|}{ Colour of the leaves $\left(\right.$ CIE L $\left.^{*} \mathrm{a}^{*} \mathrm{~b}^{*}\right)$} & \multirow{2}{*}{$\begin{array}{l}\text { Green index } \\
\text { (SPAD) }\end{array}$} & \multirow{2}{*}{$\begin{array}{l}\text { One leaf area } \\
\left(\mathrm{cm}^{2}\right)\end{array}$} & \multirow{2}{*}{$\begin{array}{l}\text { Total leaf area } \\
\left(\mathrm{m}^{2}\right)\end{array}$} \\
\hline & $\mathrm{L}^{*}$ & $\mathrm{a}^{*}$ & $\mathrm{~b}^{*}$ & & & \\
\hline Ben Alder & 35.65 & -8.64 & 17.73 & 41.3 & 36.4 & 0.87 \\
\hline Ben Conan & 34.26 & -6.51 & 12.55 & 35.7 & 56.5 & 2.43 \\
\hline Ben Gairn & 36.79 & -7.32 & 15.81 & 37.1 & 45.4 & 2.09 \\
\hline Ben Hope & 40.24 & -8.71 & 21.41 & 40.4 & 67.3 & 2.97 \\
\hline Jubilejnaja Kopania & 36.46 & -6.94 & 14.29 & 35.0 & 41.6 & 3.43 \\
\hline Saniuta & 35.74 & -7.10 & 15.07 & 38.6 & 39.0 & 2.48 \\
\hline Sjuta Kijewska & 35.58 & -7.44 & 15.85 & 36.9 & 48.7 & 2.59 \\
\hline Sofijewskaja & 33.63 & -5.67 & 10.80 & 29.9 & 46.5 & 1.67 \\
\hline 'Wernisaż' & 36.82 & -7.71 & 19.06 & 39.2 & 54.8 & 2.17 \\
\hline Ores & 37.85 & -7.47 & 17.47 & 38.4 & 52.1 & 3.93 \\
\hline Ruben & 34.21 & -6.45 & 12.40 & 34.1 & 47.9 & 2.55 \\
\hline Tiben & 35.38 & -8.23 & 16.07 & 41.5 & 40.8 & 2.83 \\
\hline Tines & 33.52 & -7.54 & 13.33 & 35.8 & 45.9 & 2.56 \\
\hline Tisel & 34.55 & -8.30 & 16.64 & 41.2 & 40.7 & 2.01 \\
\hline $\mathrm{LSD}_{0,05}$ & 2.4 & 1.1 & 3.3 & 3.7 & 16.9 & 0.31 \\
\hline $\begin{array}{l}\text { Correlation coefficients between } \\
\mathrm{L}^{*} \mathrm{a}^{*} \mathrm{~b}^{*} \text { and green index }\end{array}$ & 0.42 & $-0.88^{* *}$ & $0.83^{*}$ & - & - & - \\
\hline
\end{tabular}

${ }^{*}$ Correlation significant at the level of $\alpha 0.05,{ }^{* *}$ Correlation significant at the level of $\alpha 0.01$ 
166

chlorophyll content in the leaves by means of a Konica Minolta spectrophotometer.

\section{References}

Bakowska-Barczak A, Kolodziejczyk P (2011). Black currant polyphenols: Their storage stability and microencapsulation. Indust Crops Prod 34(2):1301-1309.

Barney DL, Hummer KE (2005). Cuirants, gooseberries and jostaberries - a guide for growers, marketers and researchers in North America. Haworth Press, Binghamptom, NY.

Borowska J (2003). Owoce i warzywa jako źródło naturalnych przeciwutleniaczy (1). Przem Ferm Owoc Warz 5:11-12.

Brennan RM (2008). Currants and gooseberries, 177-196 p. In: Hancock JF (Ed.). Temperate fruit crop breeding germplasm to genomics, Springer, Berlin.

Chang S, Tan C, Frankel EN, Barrett DM (2000). Low density lipoprotein antioxidant activity of phenolic compounds and polyphenol oxidase activity in selected clingstone peach cultivars. J Agric Food Chem 48(2):147-151.

De Gara L, De Pinto MC, Tommasi F (2003). The antioxidant systems vis-á-vis reactive species during plantpathogen interaction. Plant Physiol Biochem 41:863-870.

Eberhardt MV, Lee ChY, Liu RH (2000). Nutrition: antioxidant activity of fresh apples. Nature 405:903-904.

Ehlenfeldt MK, Prior RL (2001). Oxygen radical absorbance capacity (ORAC) and phenolic and anthocyanin concentrations in fruit and leaf tissues of highbush blueberry. J Agric Food Chem 49(5):2222-2227.

Espín JC, Soler-Rivas C, Wichers HJ, García-Viguera C (2000). Anthocyanin - based natural colorants: A new source of antiradical activity for foodstuff. J Agric Food Chem 48:15881592.

Gregorczyk A, Raczyńska A (1997). Badania korelacji między metodą Arnona a pomiarami zawartości chlorofilu za pomocą chlorofilometru. Zesz Nauk AR Szczec 181:119-123.

Halliwell B (2001). Vitamin C and genome stability. Mutat Res Fundam Mol Mech Mutagen 475(1-2):29-35.

Heinonen IM, Meyer AS, Frankel EN (1998). Antioxidant activity of berry phenolics on human lowdensity lipoprotein and liposome oxidation. J Agric Food Chem 46:4107-4112.

Hodges DM, Lester GE, Munro KD, Toivonen PMA (2004). Oxidative stress: importance for postharvest quality. Hortsci 39:924-929.

Hummer KE, Barney DL (2002). Crop reports. Currants. HortTechnol 12(3):377-388.

Kalisz S, Ścibisz I (2010). Effect of plant extract additives on the content of total polyphenols, anthocyanins, l-ascorbic acid, and antioxidant capacity of black currant nectars. Żywn Nauka Tech Jakość 5 (72):45-55.

Kalisz S, Wolniak M (2007). Zmiany wybranych wyróżników jakościowych podczas przechowywania soków odtwarzanych z koncentratów. Żywn Nauka Tech Jakość 5(54):203-212.

Keep E (1995). Currants (Ribes spp.), 235-239 p. In: Smartt J,
Simmonds NW (Eds.). Evolution of crop plants, Longman, London.

Lipecki J, Libik A (2003). Niektóre składniki warzyw i owoców o wysokiej wartości biologicznej. Folia Hort 1:16-22.

Makosz E (2006). Czarne porzeczki w Unii Europejskiej. Hasło Ogrodn 7:41-43.

Makosz E (2007). Szanse rozwoju polskiego sadownictwa. Plantpress, Kraków, 35-37 p.

Manach C, Scalbert A, Morand Ch, Remesy Ch, Jimenez L (2004). Polyphenols: food sources and bioavailability. Am J Clin Nutr 79:727-747.

Markowski J, Pluta S (2003). Wartość gospodarcza i przydatność przetwórcza wybranych genotypów porzeczki czarnej w latach 2000-2001. Cz. 1. Zesz Probl Post Nauk Roln 488:469-475.

McGlynn P (2006). Welcome back black currants: forbidden fruit making a comeback. Chronicleonline Cornell University, New York.

Mikkonen TP, Maatta KR, Hukkanen AT, Kokko HI, Torronen AR, Karenlampi SO, Karjalainen RO (2001). Flavonol content varies among black currant cultivars. J Agric Food Chem 49(7):3274-3277.

Milivojevic J, Slatnar A, Mikulic-Petkovsek M, Stampar F, Nikolic M, Veberic R (2012). The influence of early yield on the accumulation of major taste and health-related compounds in black and red currant cultivars (Ribes spp.). J Agric Food Chem 60:2682-2691.

Mladin P, Coman M, Sasnauskas A, Chiţu E, Mladin K, Ancu I, Nicola C, Sumedrea M (2009). Contributions to the agrobiological study of the black currant and blueberry within the cultivar evaluation European network scientific papers of the R.I.F.G. Pitesti. XXV 15-20 p.

Moyer RA, Hummer KE, Wrolstad RE, Finn C (2002). Antioxidant compounds in diverse ribes and rubus germplasm. Acta Hortic 585:501-505.

Ochmian I, Grajkowski J, Skupień K (2008). Effect of substrate type on the field performance and chemical composition of highbush blueberry cv. 'Patriot'. Agric Food Sci 19:69-80.

Ochmian I, Oszmiański J, Skupień K (2009). Chemical composition, phenolics and firmness of small black fruits. J Appl Bot Food Qual 83:64-69.

Ochmian I, Chełpiński P, Rozwarski R, Strzelecki R, Pantecki P, Angelov L, Stalev B (2012). The fruits quality and influence of maceration method on their fruit juice colour in two cultivars of wingrapes. Folia Pomer Univ Technol Stetin Agric, Aliment, Pisc Zootech 295(22):35-42.

Ochmian I (2013). Growth, yield and fruit quality two cultivars lowbusch blueberry. Acta Sci Pol, Hortorum Cultus 12(2):8796.

2013.

Ochmian I, Kubus M, Dobrowolska A (2013). Description of plants and assessment of chemical properties of three species from the Amelanchier genus. Dendrobiology 70:59-64.

Oszmiański J, Sożyński J (1989). Wpływ warunków otrzy- 
mywania oraz przechowywania soku z aronii na związki fenolowe i barwę. Zesz Nauk AR W rocław 184:90-95.

Oszmiański J, Wojdyło A (2005). Aronia melanocarpa phenolics and their antioxidant activity. Eur Food Res Technol 221:809-813.

Peters E (1884). Die Cultur des Beeren - Obstes nebst Angabe der empfehlenswerthesten Sorten. Verlag der Redaction der "Illustrierten Flora", Wien. http://www.archeoah.at/BeerenDateien/beerengeschichte.htm.

Pluta S (1996). Kolekcja odmian porzeczki czarnej w Corvallis, Oregon w USA jako źródło genów do hodowli odpornościowej w Polsce. Ogólnopolska Konferencja Ochrony Roślin Sadowniczych. ISiK, Skierniewice 72-74 p.

Pluta S, Żurawicz E (2008a). Deserowe odmiany - nowy cel programu hodowli porzeczki czarnej w Instytucie Sadownictwa i Kwiaciarstwa w Skierniewicach. XLV Ogólnopolska Naukowa Konferencja Sadownicza. ISiK, Skierniewice 12-15 p.

Pluta S, Żurawicz E (2008b). Suitability of the new polish blackcurrant cultivars for mechanical fruit harvesting. Proceedings of international scientific conference "Sustainable fruit growing: from plant to product" May 28-31, 2008 Jūrmala Dobele, Latvia 213-221 p.

Pluta S, Żurawicz E, Broniarek-Niemiec A (2005). Comparison of the production value of new Polish blackcurrant clones and selected foreign cultivars. Zesz Nauk ISK 13:63-68.

Pluta S, Żurawicz E, Broniarek-Niemiec A (2007). Wartość produkcyjna nowych odmian i klonów hodowlanych porzeczki czarnej oceniana w latach 2000-2006. Rocz AR Pozn CCCLXXXIII, Ogrodn 41:371-376.

Rousseau H, Roy M, Coulombe J (2002). Blackcurrant research trials in the province of Quebec, Canada with special reference to foliar diseases. Acta Hort 585:225-230.

Sweet V (1999). Hildegard of Bingen and the greening of medieval medicine. Buli Hist Med 73:381-403.

Viskelis P, Anisimoviene N, Rubinskiene M, Jankovska E, Sasnauskas A (2010). Physical properties, anthocyanins and antioxidant activity of blackcurrant berries of different maturities. J Food Agr Environ 8 (2):159-162.

Wang SY, Jiao HJ (2001). Changes in oxygen-scavenging systems and membrane lipid peroxidation during maturation and ripening in blackberry. J Agric Food Chem 49(3):1612-1619.

Wu X, Gu L, Prior RL, McKay S (2004). Characterization of anthocyanins and proanthocyanins in some cultivars of Ribes, Aronia and Sambucus and their antioxidant capacity. J Agric Food Chem 52:7846-7856. 